\title{
Ethnobotany and the Antibacterial Activity of two Indigenous Spice Plants in Healthcare System of Ogbia-Speaking People of Bayelsa State Nigeria
} \author{
Ogechukwu $^{4}$ \\ ${ }^{1}$ Department of Plant Science and Biotechnology, Federal University Otuoke, Nigeria \\ ${ }^{2}$ Department of Plant Science and Biotechnology, University of Port Harcourt, Nigeria \\ ${ }^{3}$ Department of Crop and Soil Science, Niger Delta University Bayelsa State, Nigeria \\ ${ }^{4}$ Department of Microbiology, Federal University Otuoke, Nigeria
}

Ihinmikaiye Samuel Olatokunbo ${ }^{1 *}$, Ochekwu, Edache Bernard ${ }^{2}$, Ikuli, Josiah Muonam ${ }^{3}$, Akinjagunla, Atinuke ${ }^{1}$ Odinika, Sylvia

Article History
Received: 05.12 .2020
Accepted: 17.12 .2020
Published: 30.12 .2020
Journal homepage:
http://www.easpublisher.com
Quick Response Code

Abstract: Ethnomedicinal survey and antibacterial study of ethanol and aqueous extracts
of Piper guineense and Tetrapluera tetraptera were carried out in Ogbia communities
and Microbiology Laboratory Federal University Otuoke respectively. Rapid appraisal
method and Use-Value index were applied to fetch information on ethnobotanical use of
the two spice plants (commonly used among Ogbia people in Bayelsa State), and their
antibacterial activities were tested on Staphylococcus aureus, Streptococcus pyogenes,
Escherichia coli and Pseudomonas aeruginosa. Ethnographic data shows that the
principal health-care uses of the spices correspond to gastro-intestinal treatment, and
fruits were the most important section utilized for managing health disorders. The fruit
extracts yielded strong antibacterial activity against the organisms at the treatment
regimens (200-12.5mg/ml), the zones of inhibition in both case decreases down
concentration gradients. Escherichia coli shows the widest Zone-of-Inhibition in Piper
guineense at each concentration regimen. The widest Zone-of-inhibition in Tetrapluera.
tetraptera extracts were recorded against S. aureus, and the lowest Minimun-Inhibitory-
Concentration, $2.5 \mathrm{mg} / \mathrm{ml}$ occurred at the assay of Piper guineense against E. coli, and
similar trend occurred in Tetrapleura. tetraptera extracts. Also Minimum-Inhibitory-
Concentration of $2.5 \mathrm{mg} / \mathrm{ml}$ and 5mg/ml was recorded on Streptococcus pyogene in
ethanol and aqueous extract respectively, justifying the ethnomedicinal uses of the spices
among the people.
Keywords: Ethnomedicine, Antibacterial activity, Plant extracts, test organisms, Zone of
Inhibition, MIC. Copyright $\odot 2020$ The Author(s): This is an open-access article distributed under the terms of the Creative Commons Attribution 4.0 International License (CC BY-NC 4.0) which permits unrestricted use, distribution, and reproduction in any medium for non-commercial use provided the original author and source are credited.

\section{INTRODUCTION}

Spice plants are vital components of most Nigeria dishes; they reflect the people's history, culture and geographical location. Spices are plant materials primarily use for garnishing, seasoning or enhancing the taste of local and exotic cuisines [1]; and also for cosmetic, insecticides and curative needs [2]. They are mostly plant parts such as- seeds, fruits, leaves, twig, roots, barks, buds or whole plant: which could be used fresh or dried; whole or grind. Plant species used for spices are usually aromatic and pungent by nature [3], due to the varying degree of essential oils and rich phytochemicals lock up in them [1]. FAO [4] and, Kayode \& Ogunleye [5] stressed that spice plants are the most commonly use plant in West Africa, due to their curative value [6].
The use of plant extracts as potential antibacterial agents have been well reported [7-10]. Their medicinal properties have been asserted to exert bacteriostatic and bactericidal effects [11-13] which when employ particularly in the fight against pathogens resistant to major class of antibiotics could prove effective 14]. Piper guineenses and Tetrapleura tetraptera are two spice plants commonly use in culinary, primaryly for health management among Ogbia people, who resides mostly in the tropical forest of Bayelsa State; among who spice plants are employ as tools to manage health disorder either singularly or in combination of other herbs. The antibacterial effect of these plants on certain bacteria isolates (which seem to be the main causal agents of a number of illnesses in the area) has not yet been ascertained, hence this study aimed at documenting enthobotanical information on the spices, as well as evaluating their antibacterial activities. 


\section{Methodology}

\section{Description of the Study Area}

Ogbia is one of the three Local Government Areas (LGAs) that constitute Bayelsa East senatorial district. The LGA occupies $1,670 \mathrm{~km}^{2}$, and its human populations is about 189,926 . Ogbia LGA is located on the Cartesian coordinate of Lat $04^{0} 45$ and $6^{0} 19^{1} \mathrm{~N}$ and Long $4^{0} 76$ and $6^{0} 32^{1} \mathrm{E}$, and is constituted of about 40 communities, some are situated onshore and others are offshore. In fact, Ogbia encompasses Oloibiri, a community where oil struck in quantities sufficient for commercial production in Nigeria was first found in 1956. The oil rich LGA lies within the heaviest rainfall area of Nigeria, and its mean monthly temperature is in the range of $26^{\circ \mathrm{c}}$ and $31^{0 \mathrm{c}}$. The indigenous people are predominantly subsistent farmers, yet a small proportion engages in wild fruit gathering, fishing, hunting, lumbering, palm-oil processing, weaving and trading.

\section{Ethnobotanical Survey}

A rapid appraisal method was used to gather ethnobotanical information on $P$. guineense and $T$. tetraptera, commonly used spices among indigenous people of Ogbia LGA. The information was fetched by an open-ended conversation and semi-structured questionnaire matrix following Martin [15]. This allows individual informant to express personal viewpoints freely without being interrupted or contradicted by others. Ten communities (Kolo2, Elebele, Otuabula, Opume, Ewoi, Emeyai, Oloibiri, Otuasega, Oruma and Imringi) were selected for the study. And five elderly people (in each of the community) who have maintained continuous domicile for a minimum period of twenty-five years were identified and interviewed in respect to their knowledge of the spices. Acceptability and suitability of each species were determined in respect to their reported use, using Use-Value index for one species $\left(\mathrm{UV}_{\text {is }}\right)$.

$$
\text { Use Value }\left(\mathrm{UV}_{\mathrm{is}}\right)=\frac{\sum U}{N S} \text { : }
$$

Where $\mathrm{U}$ is the sum of the total number of use citations by all informants for a given species; Ns is the total number of informants. This method quantifies the relative importance of each species based on its relative use among the informants [16]. Also data obtained were subjected to descriptive statistics such as frequency and analysis of variance using SPSS 22 version.

\section{Preparation of the Plants Extracts and Antimicrobial Analysis}

The two spice plants assessed were subjected to antimicrobial test on the basis of the information provided by the respondents. The spices (fruits of Piper guineense and seeds of Tetrapleura tetraptera) were air dried under hot air oven at $55^{\circ} \mathrm{C}$ for 3 hours and pulverized. Subsequently, thirty gram $(30 \mathrm{~g})$ of the pulverized samples were extracted successively with $300 \mathrm{ml}$ of ethanol $\left(56-60^{\circ} \mathrm{C}\right)$ and de-ionized water $(90$
- $100^{\circ} \mathrm{C}$ ) in Soxhlet extractor until the extracts were clear. The extracts were evaporated to dryness using rotary evaporator and the resulting (pasty form) extracts were stored in labeled sterile plastic containers at $4^{0} \mathrm{C}$ in a refrigerator.

\section{Test Microorganisms and Standardization}

Clinical isolates of Staphylococcus aureus, Streptococcus pyogenes, Escherichia coli and Pseudomonas aeruginosa were obtained from the Microbiology Laboratory Federal Medical Centre, Yenagoa, Bayelsa State. The microbes were maintained on nutrient agar slants in a refrigerator at $4^{0} \mathrm{C}$ prior to use.

\section{Determination of Antibacterial Activity}

The antibacterial activity was determined by agar well diffusion method of Perez et al., [17]. Bacterial inoculum was prepared by inoculating a single colony of test organisms in $5 \mathrm{ml}$ of Nutrient broth at $37^{0 \mathrm{C}}$ for 3 - 5 hours till a moderate turbidity was developed. The turbidity was matched with 0.5 McFarland standard solutions. Nutrient agar plates of Mueller Hillton were prepared and inoculated with the test organisms by spreading the bacterial inoculums on the surface of the media aseptically (streak method) with the help of sterile wire loop. Subsequently, prepared filter disc (of $6 \mathrm{~mm}$ in diameter) with different concentrations $(200 \mathrm{mg} / \mathrm{ml}, \quad 100 \mathrm{mg} / \mathrm{ml}, \quad 50 \mathrm{mg} / \mathrm{ml}$, $25 \mathrm{mg} / \mathrm{ml}$ and $12.5 \mathrm{mgm} / \mathrm{l}$ ) of both ethanol and aqueous extracts were made and placed on the plates inoculated with the test organisms. The plates were incubated at $37^{0 \mathrm{C}}$ for 24 hours. The antibacterial activity was evaluated by measuring the diameter of the zone of inhibition and recorded in $\mathrm{mm}$.

\section{Determination of the Minimum Inhibitory Concentration (MIC)}

MIC extracts of $P$. guineense and T. tetraptera on the isolate were determined using tube dilution method of Cheesbrough [18]. Various concentrations of the extracts $(20 \mathrm{mg} / \mathrm{ml}, 10 \mathrm{mg} / \mathrm{ml}, 5 \mathrm{mg} / \mathrm{ml}, 2.5 \mathrm{mg} / \mathrm{ml}$ and $1.25 \mathrm{mg} / \mathrm{ml}$ ) were prepared by making tenfold dilution of the extracts, and introduced into different test tubes containing nutrient broth inoculated with 18 hours' cultures of the test organisms. The test tubes were incubated for 24 hours at $37^{0} \mathrm{C}$. The lowest concentration of the extracts with no visible growth of the isolates was considered as the minimum inhibitory concentration for the isolate.

\section{Results AND Discussion}

The Use value (UV) quantified the relative importance, the frequency in which the spice plants were mentioned, in conjunction with the number of uses (report use) mentioned per plant species (Table-1). The Table reveals four uses of $T$. tetraptera, five uses of $P$. guineense, as well as their UV indices. Fruits were reported as the section mostly used for managing health 
disorders in the two spectrums, whereas seasoning scored the highest UV index (1.00) of the individual spice, followed closely by their use for managing gastro-intestinal disorder 0.80 and 0.88 for $T$. tetraptera and $P$. guineense respectively. This infers that seasoning is the primary use of the species; however basic acquaintance led credence to their use in health management, and this constitute the secondary use. Moreover, ethnographic data revealed that the main secondary function correspond to gastro-intestinal use, this suggests that the plants yield antibacterial activity against gastro-intestinal tract bacteria. Ethnobotanical researches executed among different ethnic groups indicated the existence of vast knowledge on medicinal plants among indigenous people [19, 20], however the wide spread use of the species could be attributed to cultural acceptability, efficiency against specific diseases, physical accessibility and economic affordability [21].

The results of antibacterial activity of ethanol and aqueous extracts of Piper guineense against the test organisms ( $S$. aureus, $S$. pyogenes, $E$. coli and $P$. aeruginos $a$ ) are presented in Figure 1 and 2 . The test organisms were associated with gastric disorder related ailments. The Figures reveal that the fruit extracts yielded strong antibacterial activity against the test organisms at the treatment regimens $(200-12.5 \mathrm{mg} / \mathrm{ml})$. The zones of inhibition in both case decrease down concentration gradients; and the extracts were significant $(p<0.05)$ in effect against the test organisms. E. coli shows the widest zone of inhibition at each concentration regimen compares to others $(\mathrm{p}<0.05)$, followed closely by $P$. aeruginosa; while $S$. aureus, yielded the least inhibitory zones in the extracts regimens (Fig 1 and 2).

The trends observed in Fig 3 and 4; favoured the ethanol extract. The widest zone of inhibition was recorded against $S$. aureus at $14.25 \mathrm{mg} / \mathrm{ml}$, and the aqueous extract of the same isolate at $10.5 \mathrm{mg} / \mathrm{ml}$; followed by $\mathrm{E}$. coli at $11.75 \mathrm{mg} / \mathrm{ml}$ and $9.75 \mathrm{mg} / \mathrm{ml}$ respectively. The least zone of inhibition was recorded against $P$. aeruginosa at $1.0 \mathrm{mg} / \mathrm{ml}$ and $0.5 \mathrm{mg} / \mathrm{ml}$ in ethanol and aqueous extracts respectively. The extracts were effective against the test organisms $(p<0.05)$, and the inhibitory zones are directly proportional to concentration. This corroborated Adeniyi et al., [22] and Banso \& Ngbede [23], who noted that Inhibitions expressed by extracts are dose dependent and large size inhibitory zones indicated the potency of the active principles of the plant.

The MIC of ethanol and aqueous extracts of $P$. guineeense and $T$. tetraptera assayed against the test organisms are shown in Table 2 and 3 respectively. The Minimum Inhibitory Concentration (MIC) of ethanol and the aqueous extracts of $P$. guineense were comparable. The lowest MIC, $2.5 \mathrm{mg} / \mathrm{ml}$ occurred at the assay of $P$. guineese against $E$. coli. Similar trend occurred in the MIC of ethanol and aqueous extracts of T. tetraptera assayed against the test organisms Table3 . However, the least MIC $(2.5 \mathrm{mg} / \mathrm{ml})$ was recorded on $S$. pyogene in ethanol extract; the value doubled $(5 \mathrm{mg} / \mathrm{ml})$ in aqueous extract of the same organism when compared. Variations in the susceptibility of the test organisms to the extracts reveal the degrees of antibacterial activities of the extracts on the isolates. The variation is attributable to physiological differences of the test organisms to the different actives compounds present in the plants $[24,8]$.

The spice plants, $P$. guineeense and $T$. tetraptera used in this study exhibited antibacterial activities: these findings justify their ethnomedicinal uses among the indigenous people, in the management of gastrointestinal disorders. Further study is required to determine the active ingredients responsible for the antibacterial effect of the spice plants.

Table-1: Status and Use-value of the Spice Plants

\begin{tabular}{|c|c|c|c|c|}
\hline IBotanical name /Family & Common name & $\begin{array}{l}\text { Habit/ Part } \\
\text { use }\end{array}$ & Report Use & $\begin{array}{l}* U V_{\text {is }} \\
\text { index }\end{array}$ \\
\hline \multirow{4}{*}{$\begin{array}{l}\text { 1. Tetrapleura tetraptera } \\
\text { (Schumach.) Taub. } \\
\text { Caesalpiniaceae }\end{array}$} & \multirow{4}{*}{$\begin{array}{l}\text { Aidan } \\
\text { (Asieyesiye) }\end{array}$} & \multirow[t]{4}{*}{ Tree/Fruit } & for: Seasoning & 1.00 \\
\hline & & & Flu treatment & 0.72 \\
\hline & & & Gastro-intestinal disorder & 0.80 \\
\hline & & & Convulsion & 0.64 \\
\hline \multirow{5}{*}{$\begin{array}{l}\text { 2. Piper guineense (Schumach. } \\
\text { \& Thonn.) } \\
\text { Piperaceae }\end{array}$} & \multirow{5}{*}{$\begin{array}{l}\text { Black pepper } \\
\text { (Eziza) }\end{array}$} & \multirow[t]{5}{*}{ Vine/Fruit } & for: Seasoning & 1.00 \\
\hline & & & Cough & 0.72 \\
\hline & & & Gastro-intestinal disorder & 0.88 \\
\hline & & & $\begin{array}{l}\text { Post partum care: to stabilize } \\
\text { womb }\end{array}$ & 0.84 \\
\hline & & & Pain relieve & 0.64 \\
\hline
\end{tabular}




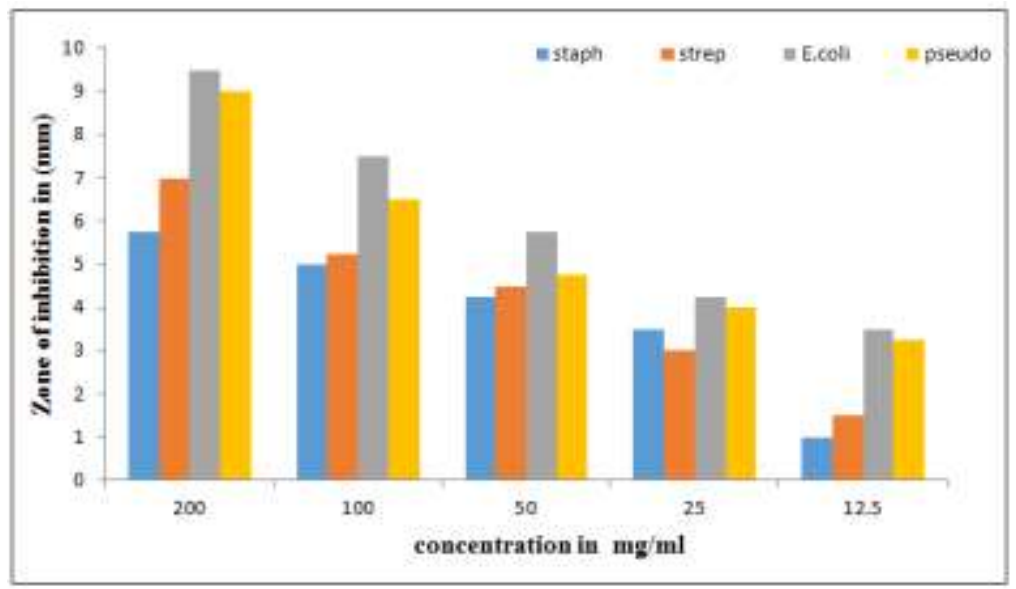

Fig-1: Antibacterial activity of ethanol extracts of $P$. guineense fruits against test organisms

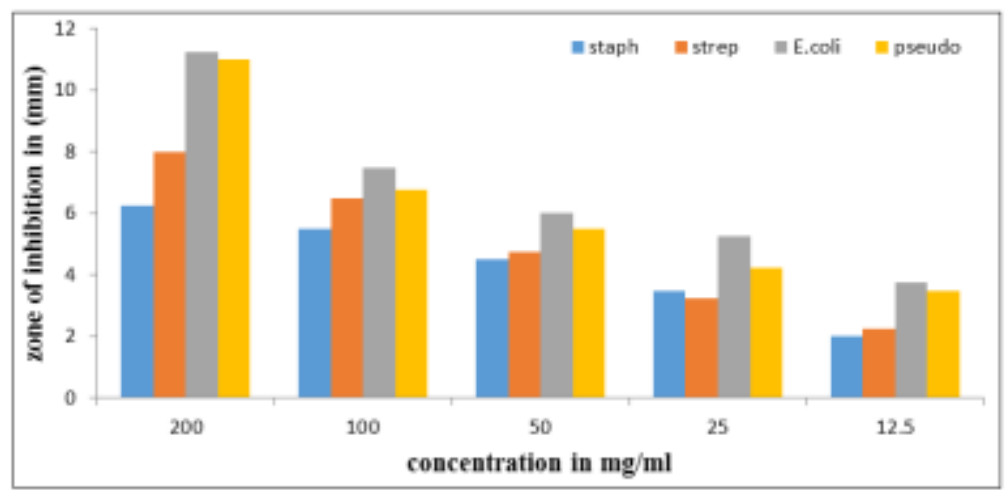

Fig-2: Antibacterial activity of aqueous extracts of p. guineense seeds against test organisms

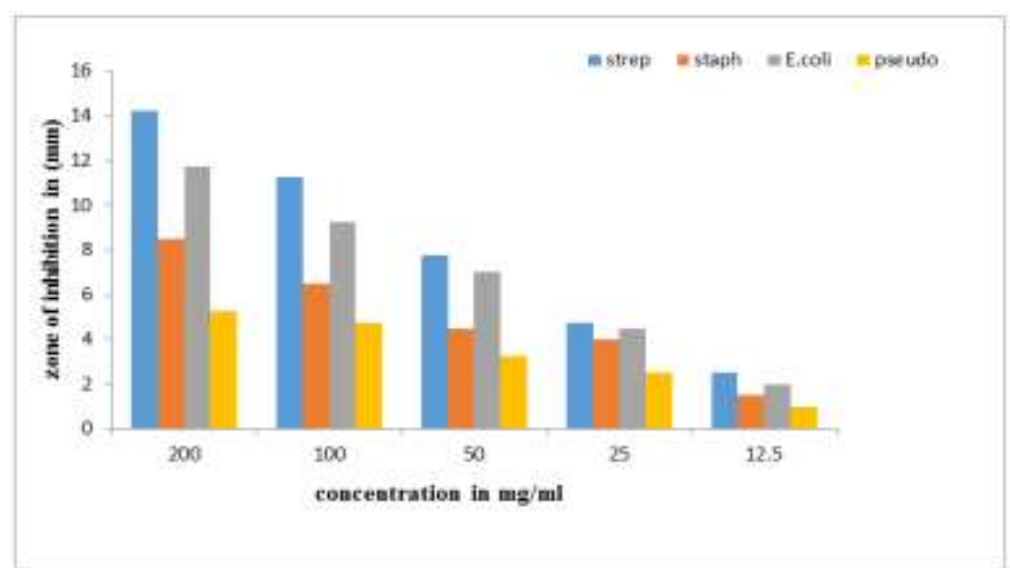

Fig-3: Antibacterial activity of ethanol extracts of $T$. tetraptera fruit against test organisms

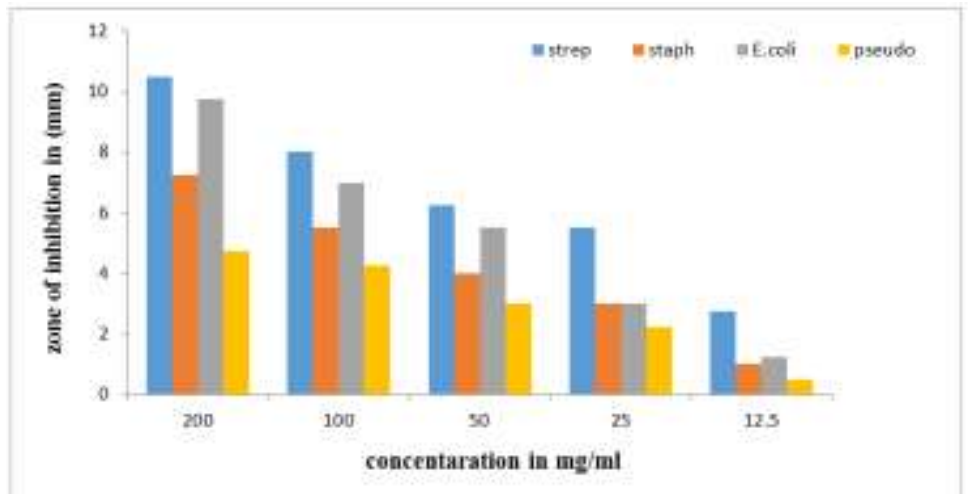

Fig-4: Antibacterial activity of aqueous extract of $T$. tetraptera fruit against test organisms 
Table-2: Minimum Inhibitoory Concentration (MIC) of Ethanol and Aqueous Extracts (of P. guineense) on Different Test Organisms

\begin{tabular}{|c|c|c|c|c|c|c|c|c|c|c|}
\hline \multirow{3}{*}{ Test Organisms } & \multicolumn{5}{|c|}{ MIC of Ethanol extract } & \multicolumn{5}{|c|}{ MIC of Aqueous extract } \\
\hline & \multicolumn{5}{|c|}{ Concentration of the Extract $(\mathrm{mg} / \mathrm{ml})$} & \multicolumn{5}{|c|}{ Concentration of the Extract $(\mathrm{mg} / \mathrm{ml})$} \\
\hline & 20 & 10 & 5 & 2.5 & 1.25 & 20 & 10 & 5 & 2.5 & 1.25 \\
\hline Staphyloccocus aureus & - & - & + & + & + & - & - & + & + & + \\
\hline Streptococcus pyogene & - & - & - & - & + & - & - & - & + & + \\
\hline Esherichia coli & - & - & - & - & + & - & - & - & - & + \\
\hline Pseudomonas aeruginosa & - & - & - & + & + & - & - & - & + & + \\
\hline $\begin{array}{l}\text { Key } \\
+=\text { Growth } \\
-\quad=\text { No growth }\end{array}$ & & & & & & & & & & \\
\hline
\end{tabular}

Table-3: MIC of Ethanol and Aqueous Extracts (of T. tetraptera) on Different Test Organisms

\begin{tabular}{|c|c|c|c|c|c|c|c|c|c|c|}
\hline \multirow{3}{*}{ Test Organisms } & \multicolumn{5}{|c|}{ MIC of Ethanol extract } & \multicolumn{5}{|c|}{ MIC of Aqueous extract } \\
\hline & \multicolumn{5}{|c|}{ Concentration of the Extract $(\mathrm{mg} / \mathrm{ml})$} & \multicolumn{5}{|c|}{ Concentration of the Extract $(\mathrm{mg} / \mathrm{ml})$} \\
\hline & 20 & 10 & 5 & 2.5 & 1.25 & 20 & 10 & 5 & 2.5 & 1.25 \\
\hline Staphyloccocus aureus & - & - & + & + & + & - & + & + & + & + \\
\hline Streptococcus pyogene & - & - & - & - & + & - & - & - & + & + \\
\hline Esherichia coli & - & - & - & + & + & - & - & + & + & + \\
\hline Pseudomonas aeruginosa & - & - & + & + & + & - & + & + & + & + \\
\hline $\begin{array}{l}\text { Key } \\
+=\text { growth } \\
-\quad=\text { No growth }\end{array}$ & & & & & & & & & & \\
\hline
\end{tabular}

\section{ACKNOWLEDGEMENT}

The authors are grateful to the indigenes of Ogbia communities for their hospitality and response to our inquires. Appreciation to Mr. Owolabi, the Chief Technologist Microbiology Laboratory Federal University Otuoke.

\section{Authors' CONTRIBUtions}

Ihinmikaiye, S. O; Ochekwu, E. B. and Odinika, S. O carried out the field ethnobotany research and draft the manuscript. Odinika, S. O., Ihinmikaiye, S. O. and Akinjagunla, A. carried out the microbial laboratory study. Ikuli, J. M. and Akinjagunla, A. participated in the field research and help confirm the species determination. All authors read and approved the final manuscript.

\section{REFERENCES}

1. Iwu, M. M. (1993). Hand book of African Medicinal Plants. Boca Raton CKC Press. 435.

2. Ihinmikaiye, S. O., Arowosegbe, S., Kayode, J., \& Oyedeji, A. (2018). Ethnobotanical survey of plant species utilized as spices among the indigenous people of Bayelsa State, Nigeria. Brazilian Journal of Biological Sciences. 5(10):461-469.

3. Achinewu, S. C., Aniena, M. I., \& Obomanu, F. G. (1995). Studies on spices of food value in the South Eastern States of Nigeria: Antioxidants Properties. J Afri Med. Plants, 18:135-139.

4. Fao - Food and Agricultural Organization. (2005). Food and Agricultural Organization Statistics. Rome.
5. Kayode, J., \& Ogunleye, T. (2008). Checklist and status of plant species used as spices in Kaduna State of Nigeria. Research Journal of Botany, 3(1):35-40.

6. Hindumathy, C. K. (2011). Invitro study of antibacterial activity of Cymbopogon citrates. World academic of Science, Engineering and Technology. 14:193-197.

7. Bonjar, G. H. S., \& Ferrohki, P. R (2004). AntiBacillus activity of some plants used in traditional medicine of Iran. Nigeria J. of Natural Products and Medicine. 8(1): 34-39.

8. Kasim, L. S., Ayodele, O., Effedua, H. I., Adejumo, O. E., Ekor, M., \& Fajemirokun, T. O. (2012). Antimicrobial activity of six selected plants against some strains of pathogenic organisms. Journal of Microbiology and Antimicrobials, 4(3):54-59.

9. Ewansiha, J. U., Garba, S. A., Mawak, J. D., \& Oyewole, O. A. (2012). Antimicrobial Activity of Cymhopogon Citratus (Lemon Grass) and It's Phytochemical Properties. Frontiers in Science, 2(6): 214-220.

10. Wemedo, S. A., Akani, N. P., \& Amadiali, A. D. (2019). Antibacterial activity of Zobo and Bay leaf extracts on enteropathogenic bacteria. Journal of Advances in microbiology. 16 (2), 1-7.

11. Okigbo, R. N., \& Igwe, D. I. (2007). The antimicrobial effect of piper guineeense 'uziza' and Phyllantus amarus 'ebe-benizo' on candida albicans and streptococcus faecalis. Acta Microbiologica et Immunologica Hungarica. 54(4):353-366. 
12. Bello, O.M., Ibitoye, T. \& Adetunji, C. (2019). Assessing antimicrobial agents of Nigeria flora. $J$. of King Saud University- Science Vol. 31. Pp13791383.

13. Oyama, M. O., Egbebi, A. O., \& Akharaiyi, F. C. (2018). Phytochemical analysis and antibacterialvactivities of some plant extracts on staphylococcus aureus isolates from patients receiving hospital treatments in Ekiti State, Nigeria. J. Herbmed Pharmacol. 9(1):14-20.

14. Essawi, T., \& Srour, M. (2000). Screening of some Palestinian medicinal plants for antibacterial activity. Journal of Ethnopharmacology. 70(3): 343-349.

15. Martin, G. J. (1995). Ethnobotany: A methods manual. Chapman and Hall publication. 1-18. DOI: 10.1007/978-1-4615-2496-0.

16. Andrade-Cetto, A., \& Heinrich, M. (2011). From the field into the lab: useful approaches to electing species based on local knowledge. Frontiesr in Pharmacology. 2(20):1-5.

17. Perez, C., Paul, M., \& Bazweque, P. (1990). An antibiotic assay by the agar well diffusion method. Acta Biol Med Exp., 15:133-115.

18. Cheesbrough, M. (2000) Medical Laboratory Manual in Tropical Countries. Butterworth Heineman Limited Oxford. 370-380.

19. Erinoso, S. M. \& Aworinde, D. O. (2018). Current outlook and future promise of Ethnobotany in
Nigeria: A review and personal observation. African Journal of Plant Science. 12(4): 73-80.

20. Anselme, B., Mireille, T. S., Yoka, J., Djego, G. J., Awede, B., Laleye A., \& Sinsin A. B. (2015). Contribution aux connaissances des principales plantes antihypertensives utilisees en medecine traditionnelle a Bassila (Benin, Afrique de l'Ouest). Revue du CAMES. Serie Pharmacopee et médecine traditionnelle africaine. 17.

21. Tilahun, T., \& Mirutse, G. (2007). Ethnobotanical study of medicinal plants used by people in Zegie Peninsula, Northwestern Ethiopia. Journal of Ethnobiology and Ethnomedicine. 3:12.

22. Adeniyi, B. A., Groves, M. J., \& Gangadharam, P. R. J. (2004). In vitro anti-mycobacterial activities of three species of Cola plant extracts (Sterculiaceae). Phytotherapy Research, 18(5):414-418

23. Banso, A., \& Ngbede, J. E. (2006). Phytochemical screening and in-vitro antifungal properties of Fagara zanthoxyloides. Journal of Food, Agriculture and Environment. 4 (3\&4):8-9.

24. Anyanwu, C. U., \& Nwosu, G. C. (2013). Assessment of the antimicrobial activity of aqueous and ethanolic extracts of Piper guineense leaves. Journal of medicinal plant research. 8(10): 436-440. 